\title{
NEW ANTHRACYCLINE ANTIBIOTICS, AURAMYCINS AND SULFURMYCINS \\ I. ISOLATION AND CHARACTERIZATION OF AURAMYCINS A AND B, AND SULFURMYCINS A AND B
}

\author{
Akiko Fujiwara, Tatsuo Hoshino, Masaaki Tazoe \\ and MitsuhiKo FujIWARA* \\ Nippon Roche Research Center, Kajiwara, Kamakura 247, Japan
}

(Received for publication September 14, 1981)

\begin{abstract}
Auramycins A and B and sulfurmycins A and B, new anthracycline antibiotics were discovered from the culture of a strain OBB-111, which was identified as Streptomyces galilaeus. The structures of the antibiotics were determined, indicating that auramycins and sulfurmycins are anthracycline glycosides of new aglycones designated auramycinone and sulfurmycinone.
\end{abstract}

Anthracycline antibiotics form one of the most widely used groups of antitumor antibiotics. Daunomycin and adriamycin are well known representatives. However, the anthracyclines are not devoid of side effects: cardiac toxicity is most serious of these. The search for new derivatives and analogues of daunomycin and adriamycin with improved activity and less toxicity has been extensive and is well documented ${ }^{1,2}$. Screening for new anthracycline antibiotics has also been pursued extensively in many laboratories and has led to the discovery of aclacinomycins ${ }^{3)}$, rhodirubins $^{4)}$, baumycins ${ }^{5)}$, musettamycin and marcellomycin ${ }^{(1)}$, roseorubicins ${ }^{7)}$, figaroic acid $^{8)}$ and rudolphomycin ${ }^{\theta)}$.

In our screening program for new anthracycline antibiotics we have discovered examples with hitherto unknown aglycones which we have designated auramycinone and sulfurmycinone ${ }^{10)}$. This report describes screening for and the production, isolation and characterization of the new antibiotics, auramycins and sulfurmycins each containing components $\mathrm{A}$ and $\mathrm{B}$ as well as the characterization of their aglycones.

\section{Results and Discussions}

Screening

From 60 soil samples, 768 colonies were picked as candidate pigment producers. These were streaked on agar medium and an agar block from each culture was tested for antibacterial activity against Micrococcus luteus. The 374 strains with antibacterial activity and pigment production were flask cultured and their antibiotic principles were physicochemically characterized by examining solvent extractability, TLC mobility and UV spectral absorption at neutral, alkaline and acidic pH's.

As a result, strain OBB-111 was selected as a producer of anthracycline antibiotics. It was identified as Streptomyces galilaeus and named S. galilaeus OBB-111.

The culture filtrate of OBB-111 contained a yellow antibiotic complex consisting of several components as detected by TLC analyses and bioautography of the TLC plates. The antibiotic complex was extracted from the culture with a solvent mixture of chloroform and methanol $(1: 1, \mathrm{v} / \mathrm{v})$ and the major components were separated by TLC. The UV, IR, MS and NMR spectral data of the purified

\footnotetext{
* Present address: Winthrop Laboratories, Tokyo, Japan
} 
products were characteristic of anthracycline structures. The two major components appeared to be aclacinomycins $\mathrm{A}$ and $\mathrm{B}^{3)}$. This was confirmed by direct comparison of physicochemical properties with authentic aclacinomycin A (a generous gift from Sanraku Ocean Co.). Besides aclacinomycins A and $\mathrm{B}$, minor quantities of the related substances, MA144-M1, -N1, -S1 and $-\mathrm{T} 1^{11}{ }^{1)}$ were also produced by strain OBB-111.

\section{Characterization of Aglycones}

When anthracyclines are analyzed by mass spectrometry, fragmentation pattern characteristic of their aglycones can be observed. All of the above components having aklavinone as the aglycone exhibited a similar fragmentation pattern derived from aklavinone ${ }^{12)}$. While characterizing all of the antibiotic components in the culture by mass fragmentation, we observed several components with fragmentation patterns different from that of aklavinone glycosides. This suggested that yellow anthracyclines with different aglycones were produced in cultures of OBB-111. In order to characterize those agylcones, all the glycosides as a mixture were hydrolyzed; the aglycones were extracted and separated from each other by column chromatography. Besides aklavinone, two minor unidentified aglycones were obtained. The pure compounds were yellow powders and were designated auramycinone and sulfurmycinone. The physicochemical properties and structures of these new aglycones have been reported in a previous paper ${ }^{10)}$.

Characterization of Auramycins and Sulfurmycins

When the crude antibiotic complex was analyzed on TLC plates (Kieselgel $\mathrm{F}_{254}$, Merck Co.) developed with toluene-methanol $(10: 1, \mathrm{v} / \mathrm{v})$, two components were detected with slightly lower $\mathrm{Rf}$ values than aclacinomycin B and another two under aclacinomycin A (Fig. 1). Mass fragmentation patterns of those components indicated that one just below aclacinomycin B and one just below aclacinomycin A were auramycinone glycosides, which we designated auramycin B and auramycin A, respectively. The other two components had mass fragmentation patterns characteristic to sulfurmycinone, which we named sulfurmycin B and sulfurmycin A, respectively. The molecular formulae, melting points and $[\alpha]_{D}^{20}$ (c $0.1, \mathrm{CHCl}_{3}$ ) of auramycins $\mathrm{A}$ and $\mathrm{B}$ and sulfurmycins $\mathbf{A}$ and $\mathbf{B}$ are summarized in Table 1. IR and ${ }^{1} \mathrm{H}$ NMR spectra of auramycins $\mathrm{A}$ and $\mathrm{B}$
Fig. 1. TLC pattern of crude antibiotic complex.

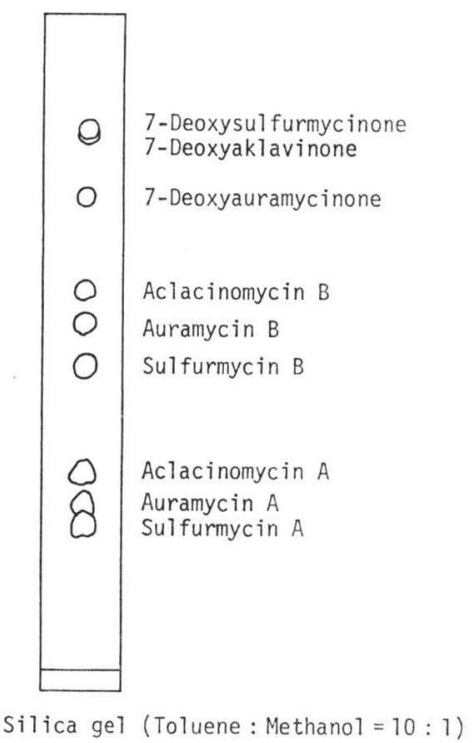

Table 1. Physicochemical properties of auramycins and sulfurmycins.

\begin{tabular}{c|c|c|c|c}
\hline & Auramycin A & Auramycin B & Sulfurmycin A & Sulfurmycin B \\
\hline Molecular formula & $\mathrm{C}_{41} \mathrm{H}_{51} \mathrm{NO}_{15}$ & $\mathrm{C}_{41} \mathrm{H}_{48} \mathrm{NO}_{15}$ & $\mathrm{C}_{43} \mathrm{H}_{53} \mathrm{NO}_{18}$ & $\mathrm{C}_{43} \mathrm{H}_{51} \mathrm{NO}_{18}$ \\
Melting point $\left({ }^{\circ} \mathrm{C}\right)$ & $141^{\circ} \mathrm{C}$ & $161^{\circ} \mathrm{C}$ & $140^{\circ} \mathrm{C}$ & $149^{\circ} \mathrm{C}$ \\
{$[\alpha]_{\mathrm{D}}^{20}\left(c 0.1, \mathrm{CHCl}_{3}\right)$} & $-8.0^{\circ}$ & $-8.0^{\circ}$ & $-23.3^{\circ}$ & $-21.5^{\circ}$ \\
\hline
\end{tabular}


Fig. 2. IR spectra of auramycins A and B.

\section{Auramycin A}

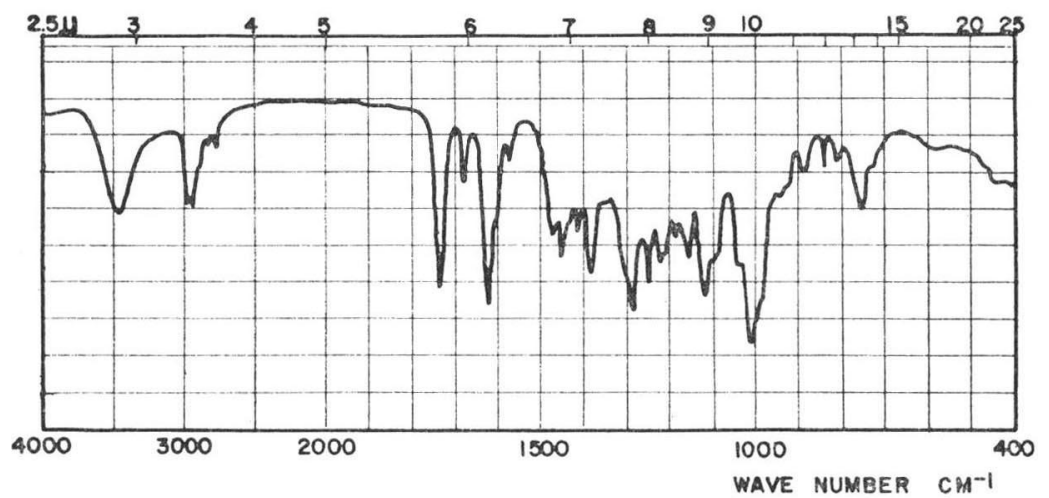

\section{Auramycin B}

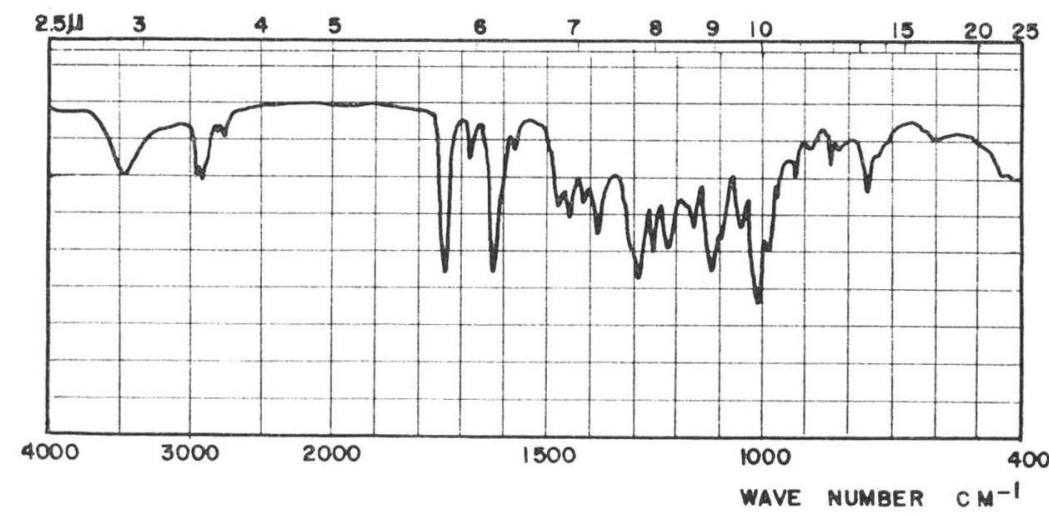

and sulfurmycins A and B are shown in Fig. 2 to Fig. 5, respectively. When auramycins A and B were reductively cleaved by liver enzyme, 7-deoxyauramycinone was obtained, indicating that they are glycosides of auramycinone at the $\mathrm{C}-7$ position.

Structures of Auramycin A and Sulfurmycin A

On hydrolysis of auramycin A with $0.1 \mathrm{~N} \mathrm{HCl}$ at $95^{\circ} \mathrm{C}$, three sugars were detected by TLC with $n$ $\mathrm{BuOH}-\mathrm{CH}_{3} \mathrm{COOH}-\mathrm{H}_{2} \mathrm{O}(4: 1: 1)$. These were identified as rhodosamine, 2-deoxyfucose and cinerulose by direct comparison with samples obtained by hydrolysis of aclacinomycin A. By hydrolysis under mild conditions, a yellow pigment I and a disaccharide II were separately obtained after silica gel column chromatography. On hydrolysis under stronger conditions, I gave auramycinone and rhodosamine. Acetylation of II with acetic anhydride yielded two anomeric diacetates. The proton magnetic resonance spectrum of one of the anomers (Fig. 6) was completely identical with data reported for the $\alpha$ anomer of a disaccharide diacetate obtained by similar treatment of cinerubin $\mathrm{A}^{13)}$. Furthermore, treatment of auramycin A with methanol- $\mathrm{HCl}$ gave a methyl glycoside with spectral data coinciding with those reported for the methyl glycoside from aclacinomycin $\mathrm{A}^{14)}$. These results, and a comparison of its properties with other data reported for aclacinomycin $\mathrm{A}^{14)}$ indicated that auramycin $\mathrm{A}$ was Lcinerulosyl-2-deoxy-L-fucosyl-L-rhodosaminyl auramycinone. In a similar manner, the structure of 
Fig. 3. IR spectra of sulfurmycins A and B.

\section{Sulturmycin A}

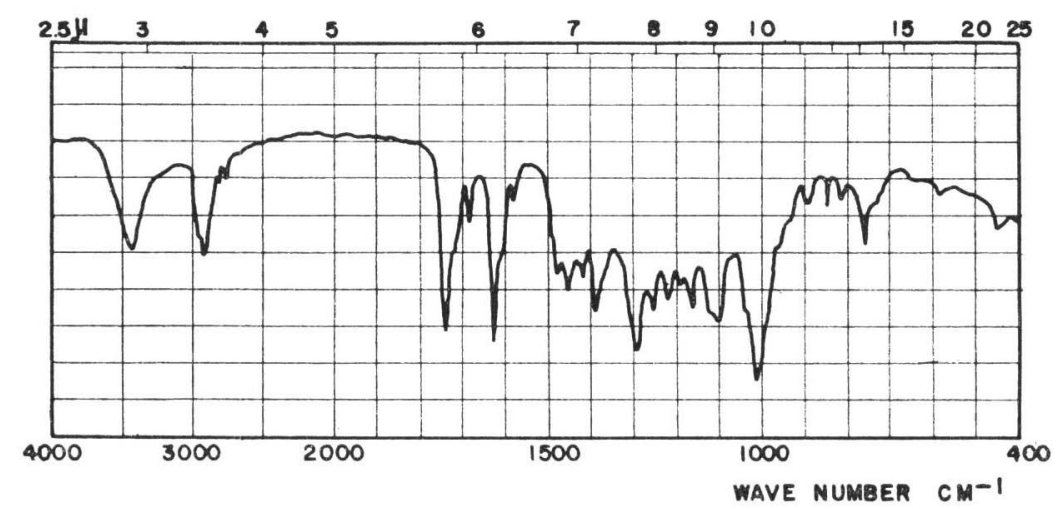

\section{Sulfurmycin B}

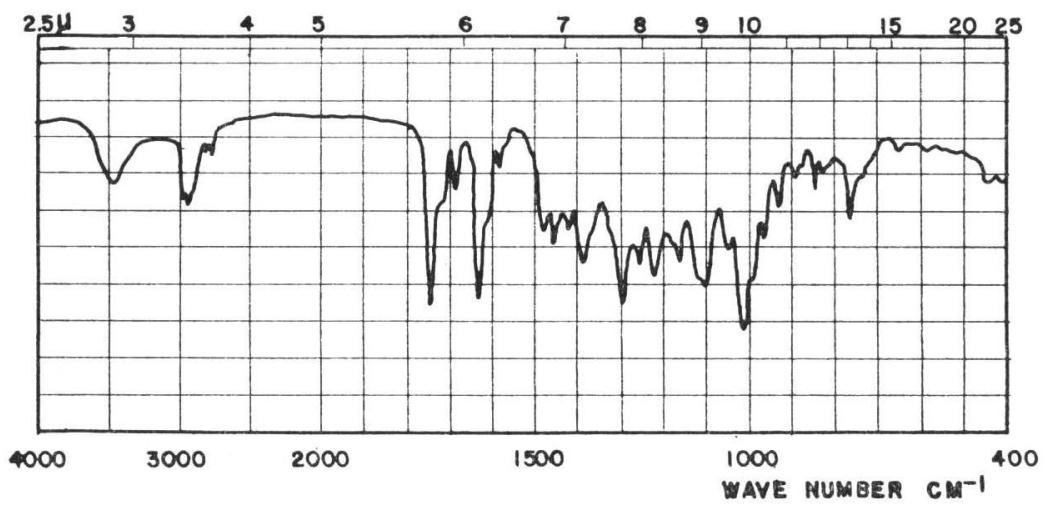

sulfurmycin A was determined to be L-cinerulosyl-2-deoxy-L-fucosyl-L-rhodosaminyl sulfurmycinone (Fig. 9). CMR spectra of auramycin A and sulfurmycin A are shown in Table 2.

\section{Structures of Auramycin B and Sulfurmycin B}

On hydrolysis of auramycin B at room temperature, a yellow pigment III and a disaccharide IV were obtained. Hydrolysis of III under stronger conditions gave auramycinone and rhodosamine. Acetylation of IV with acetic anhydride in pyridine yielded two anomeric diacetates. Each was obtained pure after silica gel column chromatography. The ${ }^{1} \mathrm{H}$ NMR spectrum of one (Fig. 7) was identical with that of the $\beta$-anomer of a disaccharide acetate obtained by the same treatment of cinerubin $\mathrm{B}^{15}$. Similarly, the ${ }^{1} \mathrm{H}$ NMR spectrum of the methyl glycoside (Fig. 8) which was obtained by methanolysis of auramycin $\mathbf{B}$ coincided with that reported for cinerubin $\mathbf{B}^{15)}$. Thus, the structure of $\mathbf{I V}$ was concluded to be 2-deoxy-L-fucosyl-L-cinerulose B with the two sugars linked to each other in the same manner as in cinerubin B and aclacinomycin B (Fig. 9). The CMR spectra of auramycin B and sulfurmycin B are shown in Table 2.

\section{Biological Activities}

The antimicrobial activities of auramycins A and B and sulfurmycins A and B are shown in Table 3. They showed marked antibacterial activity against Gram-positive bacteria and Mycobacterium 
Fig. 4. ${ }^{1} \mathrm{H}$ NMR spectra of auramycins A and B.
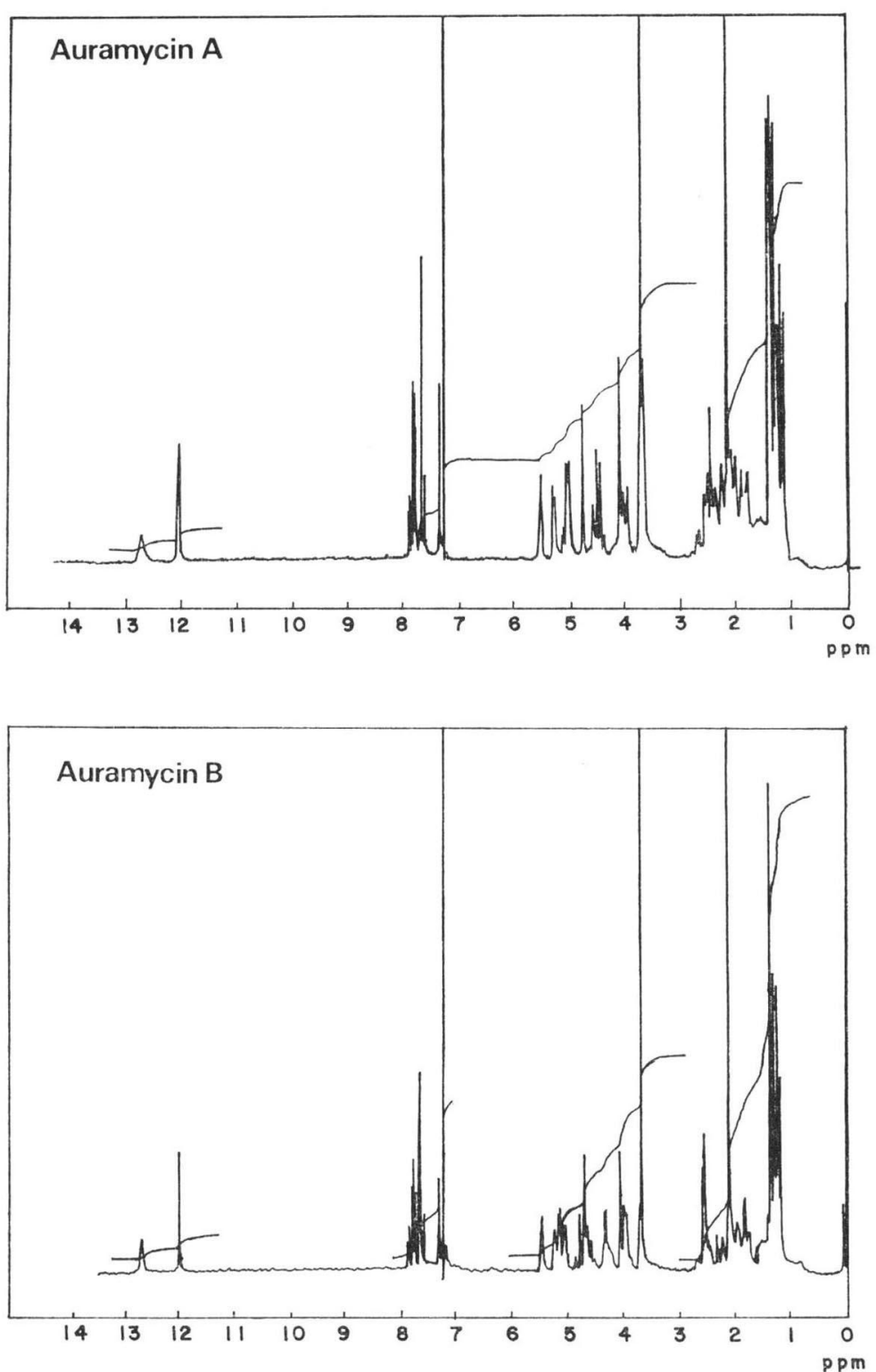

smegmatis. All the glycosides also exhibited antitumor activity against P388 and L1210 leukemia in mice at doses of $1.5 \sim 15 \mathrm{mg} / \mathrm{kg} /$ day administered intraperitoneally on days 1,5 and 9 .

\section{Experimental}

\section{General}

Melting points were determined with a Yanagimoto micro melting point apparatus, type MP-S3, and were not corrected. Infrared absorption spectra were measured with a Hitachi EPI-G3 spectrophotometer (KBr pellets) and mass spectra with a Hitachi RMU-6M spectrometer and JEOL JMS-D300 mass spectrometer. NMR spectra were recorded on a JEOL FX-100 spectrometer. Chemical shifts 
Fig. 5. ${ }^{1} \mathrm{H}$ NMR spectra of sulfurmycins A and B.
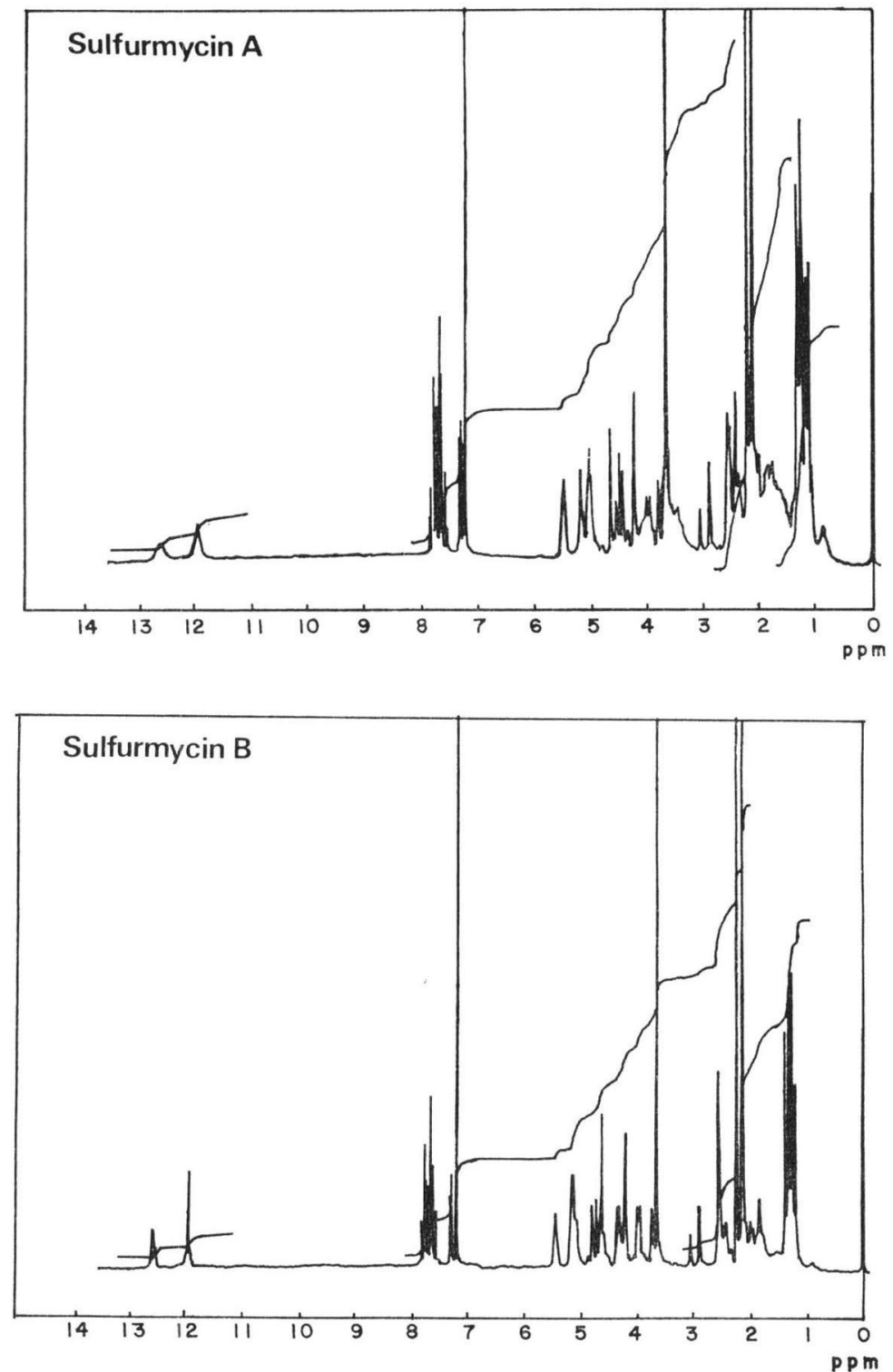

are given in $\delta$ values with tetramethylsilane as an internal standard. Abbreviation: $\mathrm{s}=$ singlet, $\mathrm{d}=$ doublet, $\mathrm{dd}=$ doublet of doublets, $\mathrm{t}=$ triplet and $\mathrm{m}=$ multiplet. Optical rotations were determined using a Perkin-Elmer polarimeter.

For thin-layer chromatography, silica gel $\mathrm{F}_{254}$ plates, (Merck Co.) were used. For sugar analysis, the plates were sprayed with $5 \% p$-anisaldehyde and $5 \%$ sulfuric acid in ethanol and heated at $90^{\circ} \mathrm{C}$ for color development.

Column chromatography was carried out with silica gel (Merck Co.), 0.063 to $0.2 \mathrm{~mm}$, and Sephadex LH-20 (Pharmacia Fine Chemicals Co.). Preparative HPLC was carried out with a Prep PAK-500/ SILICA (Waters Associates, Inc.) column and Prep LC/System 500 (Waters).

Fermentation and Isolation

Spores scraped from an agar slant of Streptomyces galilaeus OBB-111 were transferred to 500-ml 
Fig. $6 .{ }^{1} \mathrm{H}$ NMR spectrum of disaccharide diacetate ( $\alpha$-anomer) from auramycin $\mathrm{A}$.

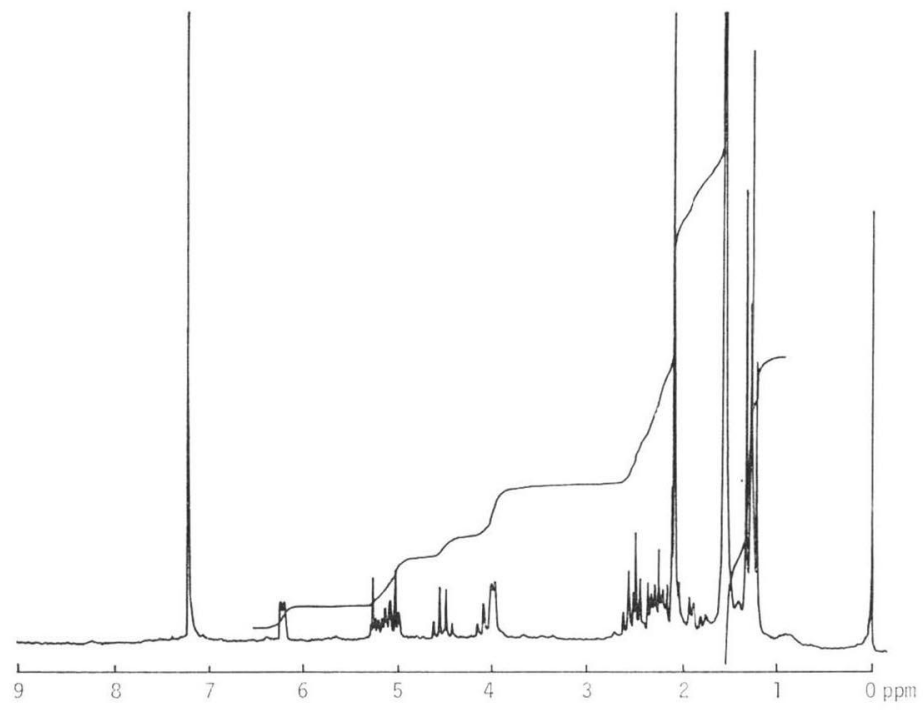

Fig. 7. ${ }^{1} \mathrm{H}$ NMR spectrum of disaccharide acetate ( $\beta$-anomer) from auramycin $\mathbf{B}$.

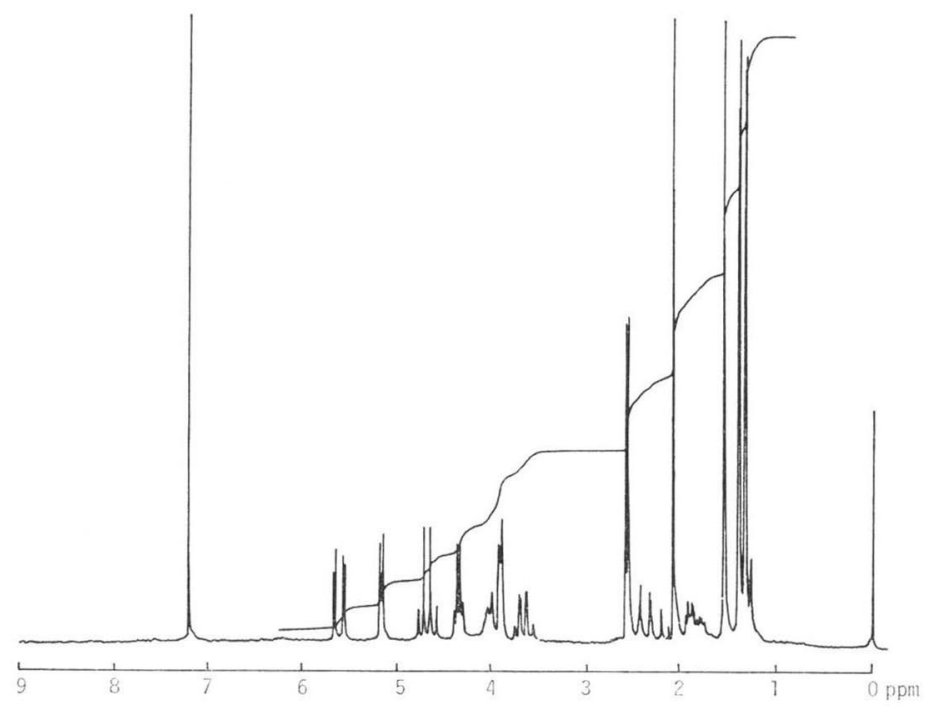

Erlenmeyer flasks each containing $100 \mathrm{ml}$ of sterilized medium consisting of $20 \mathrm{~g}$ glucose, $20 \mathrm{~g}$ soluble starch, $5 \mathrm{~g}$ S-3 meat (Ajinomoto Co.), $2.5 \mathrm{~g}$ yeast extract (Daigo Eiyo-Kagaku Co.), $1 \mathrm{~g} \mathrm{~K}_{2} \mathrm{HPO}_{4}, 1 \mathrm{~g}$ $\mathrm{MgSO}_{4} \cdot 7 \mathrm{H}_{2} \mathrm{O}, 3 \mathrm{~g} \mathrm{NaCl}$ and $3 \mathrm{~g} \mathrm{CaCO}_{3}$ made up to one liter with tap water. The flasks were incubated at $27^{\circ} \mathrm{C}$ for 72 hours on a rotary shaker $(180 \mathrm{rpm})$. Six hundreds $\mathrm{ml}$ of the vegetative culture was transferred to a 50-liter jar fermentor containing 30 liters of production medium consisting of $20 \mathrm{~g}$ glucose, $20 \mathrm{~g}$ soluble starch, $10 \mathrm{~g}$ Pharmamedia (Traders Oil Mill Co., USA), $1 \mathrm{~g} \mathrm{~K} \mathrm{HPO}_{4}, 1 \mathrm{~g} \mathrm{MgSO}_{4} \cdot 7 \mathrm{H}_{2} \mathrm{O}$, $3 \mathrm{~g} \mathrm{NaCl}, 3 \mathrm{~g} \mathrm{CaCO}_{3}$ and $1 \mathrm{~g}$ Nissan Disfoam CA-115 made up to one liter with tap water. Cultivation was carried out at $27^{\circ} \mathrm{C}$ with agitation at $350 \mathrm{rpm}$ and aeration of $1 \mathrm{v} / \mathrm{v}$ medium.

After 90 hours of cultivation, the culture ( $c a .30$ liters) was centrifuged. The cell cake was suspended in 15 liters of methanol, stirred and filtered. To the methanol extract ( 15 liters $\times 2), 30$ liters of chloroform and 30 liters of water were added and mixed, and the chloroform layer was recovered. The cul- 
Fig. 8. ${ }^{1} \mathrm{H}$ NMR spectrum of methyl glycoside.

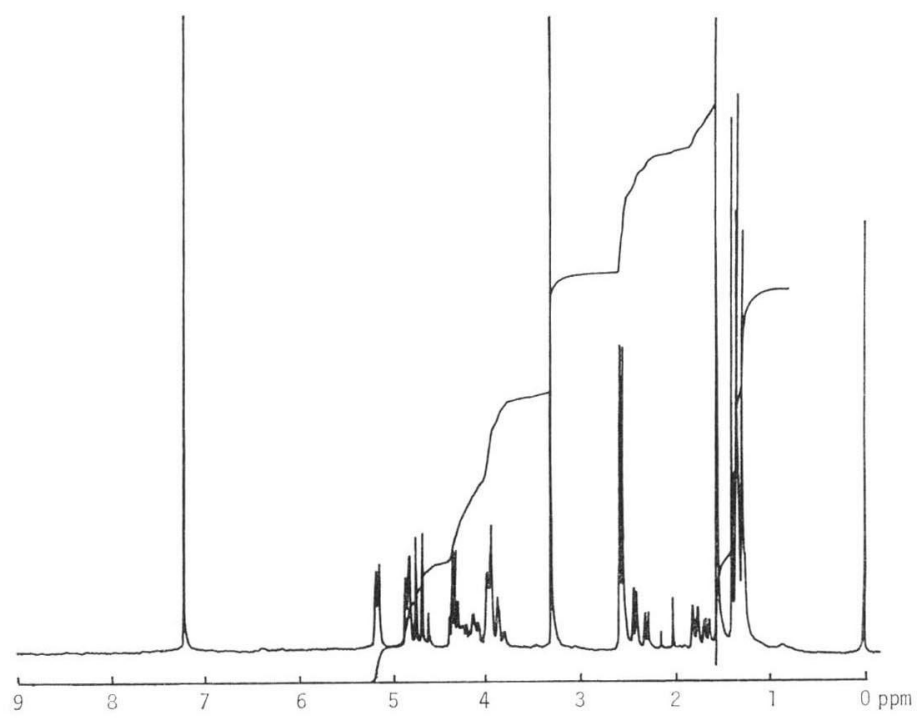

Fig. 9. Structures of auramycins and sulfurmycins.
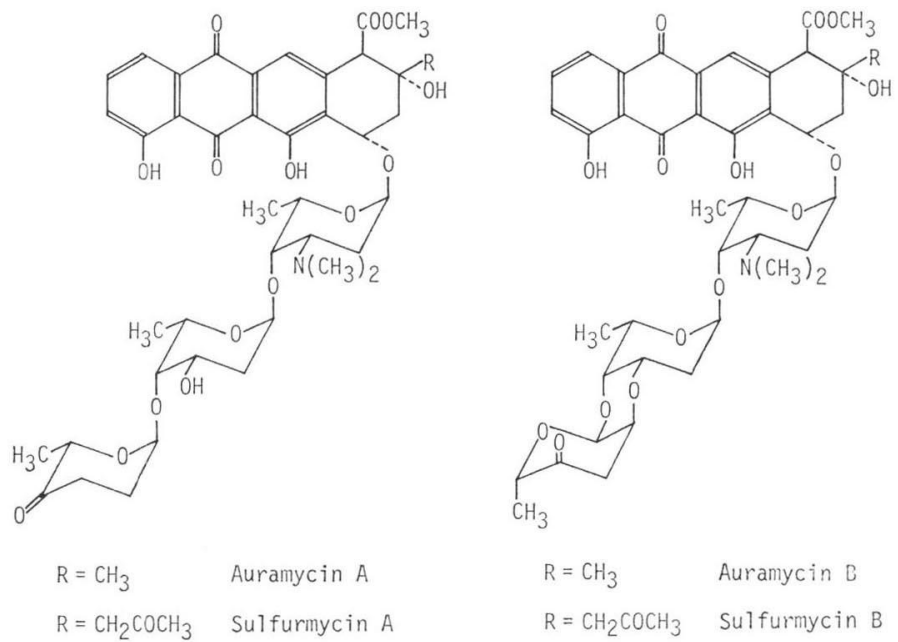

ture filtrate was extracted with 60 liters of chloroform - methanol (1:1) mixture, and the chloroform layer was obtained. The chloroform extracts from cells and filtrate were combined and evaporated to a small volume $(50 \sim 60 \mathrm{ml})$. The concentrate was diluted with $n$-hexane to precipitate yellow pigments, which were dried in vacuo to give $4.8 \mathrm{~g}$ of yellow powder.

The crude antibiotic complex (4.8 g) was fractionated by Sephadex LH-20 column chromatography with a chloroform - methanol (2:1) mixture. As a result, two distinct bands of yellow pigments were noted. The yellow solid (1.2 g) obtained from the first band consisted of aglycone-type pigments, which were subjected to silica gel column chromatography developed with a chloroform - $n$-hexane (4:1) mixture. There were obtained $43 \mathrm{mg}$ of 7-deoxysulfurmycinone, $68 \mathrm{mg}$ of 7-deoxyauramycinone and $55 \mathrm{mg}$ of 7 -deoxyaklavinone $\left(\mathrm{mp} 230^{\circ} \mathrm{C}\right)$.

7-Deoxyauramycinone: $\operatorname{mp~} 200^{\circ} \mathrm{C} ;[\alpha]_{\mathrm{D}}^{20}+81.2^{\circ}\left(c \quad 0.1, \mathrm{CHCl}_{3}\right) ; \nu_{\max }^{\mathrm{KBr}} \mathrm{cm}^{-1} 1730,1675,1620$; PMR $\left(\mathrm{CDCl}_{3}\right) \delta$ in ppm 12.45 (s), 12.05 (s), 7.76 (d), 7.65 (t), 7.60 (s), 7.27 (d), 3.90 (s), 3,74 (s), $3.04 \sim$ 
Table 2. ${ }^{13} \mathrm{C}$ Chemical shift assignments (ppm).

\begin{tabular}{|c|c|c|c|c|}
\hline $\mathrm{C}$ & Auramycin A & Auramycin B & Sulfurmycin A & Sulfurmycin B \\
\hline 5 & 192.6 & 192.6 & 192.6 & 192.6 \\
\hline 12 & 181.1 & 181.1 & 181.1 & 181.1 \\
\hline 15 & 171.3 & 171.3 & 170.7 & 170.7 \\
\hline 4 & 162.5 & 162.5 & 162.5 & 162.5 \\
\hline 6 & 162.0 & 162.0 & 162.1 & 162.0 \\
\hline $10 \mathrm{a}$ & 142.4 & 142.4 & 141.7 & 141.7 \\
\hline 2 & 137.3 & 137.3 & 137.3 & 137.3 \\
\hline $12 \mathrm{a}$ & 133.4 & 133.4 & 133.4 & 133.4 \\
\hline $6 a$ & 132.8 & 132.9 & 132.7 & 132.8 \\
\hline $11 \mathrm{a}$ & 131.2 & 131.1 & 131.3 & 131.2 \\
\hline 3 & 124.7 & 124.7 & 124.7 & 124.7 \\
\hline 11 & 120.8 & 120.9 & 121.0 & 120.9 \\
\hline 1 & 120.1 & 120.1 & 120.1 & 120.1 \\
\hline $4 a$ & 115.8 & 115.7 & 115.8 & 115.8 \\
\hline $5 \mathrm{a}$ & 114.6 & 114.6 & 114.7 & 114.7 \\
\hline 7 & 70.2 & 70.2 & 69.9 & 69.9 \\
\hline 9 & 69.8 & 69.7 & 71.0 & 71.0 \\
\hline 10 & 58.1 & 58.1 & 56.7 & 56.8 \\
\hline 16 & 52.4 & 52.4 & 52.6 & 52.6 \\
\hline 8 & 36.6 & 36.6 & 34.7 & 34.6 \\
\hline 13 & 27.4 & 27.4 & 51.0 & 50.9 \\
\hline 14 & - & - & 209.9 & 208.1 \\
\hline $14 \mathrm{a}$ & - & - & 32.5 & 32.5 \\
\hline $1^{\prime}$ & 101.3 & 101.2 & 101.5 & 101.4 \\
\hline $2^{\prime}$ & 29.2 & 29.2 & 29.2 & 29.2 \\
\hline $3^{\prime}$ & 61.5 & 61.5 & 61.5 & 61.5 \\
\hline $4^{\prime}$ & 74.0 & 74.2 & 74.2 & 74.3 \\
\hline $5^{\prime}$ & 66.8 & 65.3 & 66.7 & 65.2 \\
\hline $6^{\prime}$ & 16.9 & 17.9 & 17.0 & 17.9 \\
\hline $\mathrm{NMe}_{2}$ & 43.2 & 43.1 & 43.2 & 43.2 \\
\hline $1^{\prime \prime}$ & 100.0 & 99.0 & 100.1 & 99.0 \\
\hline $2^{\prime \prime}$ & 34.3 & 27.0 & 34.3 & 27.0 \\
\hline $3^{\prime \prime}$ & 65.3 & 67.3 & 65.3 & 67.3 \\
\hline $4^{\prime \prime}$ & 82.8 & 68.3 & 82.9 & 68.3 \\
\hline $5^{\prime \prime}$ & 68.4 & 66.9 & 68.5 & 66.9 \\
\hline $6^{\prime \prime}$ & 17.9 & 16.0 & 17.9 & 16.0 \\
\hline $1^{\prime \prime \prime}$ & 99.3 & 91.5 & 99.3 & 91.5 \\
\hline $2^{\prime \prime \prime}$ & 27.7 & 63.0 & 27.7 & 63.8 \\
\hline $3^{\prime \prime \prime}$ & 33.5 & 39.7 & 33.5 & 39.7 \\
\hline $4^{\prime \prime \prime}$ & 209.8 & 208.0 & 209.9 & 208.1 \\
\hline $5^{\prime \prime \prime}$ & 71.7 & 77.9 & 71.8 & 77.9 \\
\hline $6^{\prime \prime \prime}$ & 14.8 & 16.1 & 14.8 & 16.1 \\
\hline
\end{tabular}

$2.85(\mathrm{~m}), 2.48 \sim 2.17(\mathrm{~m}), 1.96(\mathrm{~m}), 1.82(\mathrm{~m}), 1.42(\mathrm{~s})$; MS m/z $382\left(\mathrm{M}^{+}\right)$; M.W. 382; Anal. Found: C 65.42, H 4.22, O 30.36: Calcd. for $\mathrm{C}_{21} \mathrm{H}_{18} \mathrm{O}_{7}$ : C 65.95, H 4.75, O $29.3 \%$, M.W. 382.1 . 
Table 3. Antimicrobial spectrum of auramycins and sulfurmycins.

\begin{tabular}{|c|c|c|c|c|c|}
\hline \multirow{2}{*}{\multicolumn{2}{|c|}{ Strain }} & \multicolumn{4}{|c|}{$\mathrm{MIC}(\mu \mathrm{g} / \mathrm{ml})$} \\
\hline & & Auramycin A & Auramycin B & Sulfurmycin A & Sulfurmycin B \\
\hline B. subtilis & IAM 1027 & 3.12 & 0.78 & 0.78 & 0.78 \\
\hline M. luteus & IAM 1009 & 0.1 & 0.05 & 0.1 & 0.1 \\
\hline M. flavus & ATCC 10240 & 0.1 & 0.05 & 0.2 & 0.1 \\
\hline S. aureus 209P & IAM 1011 & 1.56 & 0.39 & 0.78 & 0.78 \\
\hline S. epidermidis & IFO 12993 & 3.12 & 1.56 & 3.12 & 1.56 \\
\hline M. smegmatis & IFO 13167 & 6.25 & 3.13 & 25.0 & 6.25 \\
\hline E. coli $\mathrm{K}-12$ & IAM 1264 & $>100$ & $>100$ & $>100$ & $>100$ \\
\hline P. aeruginosa & IFO 12689 & $>100$ & $>100$ & $>100$ & $>100$ \\
\hline C. albicans & ATCC 10231 & $>100$ & $>100$ & $>100$ & $>100$ \\
\hline
\end{tabular}

7-Deoxysulfurmycinone: $\operatorname{mp} 219.5^{\circ} \mathrm{C} ;[\alpha]_{\mathrm{D}}^{20}+73.9^{\circ}\left(c 0.1, \mathrm{CHCl}_{3}\right) ; \nu_{\max }^{\mathrm{KBr}} \mathrm{cm}^{-1} 1740,1720,1675$, 1620; PMR $\left(\mathrm{CDCl}_{3}\right) \delta$ in ppm 12.47 (s), 12.09 (s), $7.76(\mathrm{~d}), 7.65(\mathrm{t}), 7.60$ (s), 7.27 (d), 4.43 (d), $4.16(\mathrm{~s})$, 3.72 (s), $3.03 \sim 2.84(\mathrm{~m})$ overlap 2.79 (d, d), 2.25 (s), $2.07 \sim 2.00(\mathrm{~m})$; MS m/z $424\left(\mathrm{M}^{+}\right)$; M.W. 424; Anal. Found: C 64.95, H 4.58, O 30.47: Calcd. for $\mathrm{C}_{23} \mathrm{H}_{20} \mathrm{O}_{8}$ : C 65.08, H 4.75, O 30.17\%, M.W. 424.1.

The yellow solid $(2.1 \mathrm{~g})$ obtained from the second band consisted of auramycins, sulfurmycins and aclacinomycins. It was fractionated by column chromatography on silica gel using gradient elution with a chloroform - methanol mixture (100:0 95:5). Aclacinomycin B, auramycin B, sulfurmycin B, aclacinomycin A, auramycin A and sulfurmycin A were eluted in this order. Each component was further purified by preparative HPLC developed with a methylene chloride - methanol (99:1 98:2) mixture. As a result, $377 \mathrm{mg}$ of aclacinomycin B ( $\left.\mathrm{mp} 162^{\circ} \mathrm{C}\right), 98 \mathrm{mg}$ of auramycin $\mathrm{B}, 122 \mathrm{mg}$ of sulfurmycin $\mathrm{B}, 150 \mathrm{mg}$ of aclacinomycin $\mathrm{A}\left(\mathrm{mp} 142^{\circ} \mathrm{C}\right), 54 \mathrm{mg}$ of auramycin $\mathrm{A}$ and $68 \mathrm{mg}$ of sulfurmycin $\mathrm{A}$ were obtained as yellow powders.

Auramycin B: $m p 161^{\circ} \mathrm{C}(\mathrm{dec}.) ;[\alpha]_{\mathrm{D}}^{20}-8.0^{\circ}\left(c 0.1, \mathrm{CHCl}_{3}\right) ; 2_{\max }^{\mathrm{KBr}} \mathrm{cm}^{-1} 1740,1680,1620$; PMR $\left(\mathrm{CDCl}_{3}\right) \delta$ in ppm $12.69(\mathrm{~s}), 12.02(\mathrm{~s}), 7.81(\mathrm{~d}), 7.67$ (s) (t) overlap, 7.30 (d), $5.48(\mathrm{~s}), 5.43 \sim 3.75(\mathrm{~m})$ overlap 4.67 (s) and 4.10 (s), 3.70 (s), 2.72 0.90 (m) overlap 2.14 (s); M.W. 795; Anal. Found: C 61.38, $\mathrm{H}$ 6.17, O 30.67, N 1.78: Calcd. for $\mathrm{C}_{41} \mathrm{H}_{49} \mathrm{O}_{15} \mathrm{~N}$ : C 61.86, H 6.21, O 30.17, N 1.76, M.W. 795.3.

Sulfurmycin B: $\operatorname{mp~} 149^{\circ} \mathrm{C}($ dec. $) ;[\alpha]_{\mathrm{D}}^{20}-21.5^{\circ}\left(c 0.1, \mathrm{CHCl}_{3}\right) ; \nu_{\max }^{\mathrm{KBr}} \mathrm{cm}^{-1} ; 1740,1680,1630$; PMR $\left(\mathrm{CDCl}_{3}\right) \delta$ in ppm 12.67 (s), 12.01 (s), 7.81 (d), 7.67 (s) (t) overlap, 7.30 (d), 5.48 (s), 5.43 3.75 (m) overlap 4.67 (s) and $4.25(\mathrm{~s}), 3.70(\mathrm{~s}), 3.50 \sim 0.90(\mathrm{~m})$ overlap $2.25(\mathrm{~s})$ and $2.16(\mathrm{~s})$; M.W. 837; Anal. Found: C 60.94, H 6.32, O 31.16, N 1.58: Calcd. for $\mathrm{C}_{43} \mathrm{H}_{51} \mathrm{O}_{10} \mathrm{~N}$ : C 61.62, H 6.14, O 30.57, N 1.67, M.W. 837.3.

Auramycin A: $\mathrm{mp} 141^{\circ} \mathrm{C}(\mathrm{dec}.) ;[\alpha]_{\mathrm{D}}^{20}-8.0^{\circ}\left(c 0.1, \mathrm{CHCl}_{3}\right) ; \nu_{\max }^{\mathrm{KBr}} \mathrm{cm}^{-1} 1740,1680,1620$; PMR $\left(\mathrm{CDCl}_{3}\right) \delta$ in ppm; 12.67 (s), $12.02(\mathrm{~s}), 7.81$ (d), 7.67 (s) (t) overlap, 7.30 (d), $5.52(\mathrm{~s}), 5.43 \sim 3.75(\mathrm{~m})$ overlap $4.76(\mathrm{~s})$ and 4.10 (s), $3.70(\mathrm{~s}), 2.72 \sim 0.90(\mathrm{~m})$ overlap 2.14 (s); M.W. 797; Anal. Found: C 60.82, $\mathrm{H}$ 6.58, O 30.96, N 1.64: Calcd. for $\mathrm{C}_{41} \mathrm{H}_{51} \mathrm{O}_{15} \mathrm{~N}$ : C 61.71, H 6.45, O 30.08, N 1.76, M.W. 797.3.

Sulfurmycin A: $\operatorname{mp~} 140^{\circ} \mathrm{C}(\mathrm{dec}.) ;[\alpha]_{\mathrm{D}}^{20}-23.3^{\circ}\left(c 0.1, \mathrm{CHCl}_{3}\right) ; \nu_{\max }^{\mathrm{KBr}} \mathrm{cm}^{-1} 1740,1680,1630 ; \mathrm{PMR}$ $\left(\mathrm{CDCl}_{3}\right) \delta$ in ppm 12.67 (s), 12.02 (s), 7.81 (d), 7.67 (s) (t) overlap 7.30 (d), 5.51 (s), 5.43 3.75 (m) overlap $4.68(\mathrm{~s})$ and $4.27(\mathrm{~s}), 3.70(\mathrm{~s}), 3.50 \sim 0.90(\mathrm{~m})$ overlap $2.25(\mathrm{~s})$ and $2.16(\mathrm{~s})$; M.W. 839; Anal. Found: C 61.16, H 6.83, O 30.47, N 1.54: Calcd. for $\mathrm{C}_{43} \mathrm{H}_{53} \mathrm{O}_{18} \mathrm{~N}$ : C 61.48, H 6.36, O 30.49, N 1.67, M.W. 839.3.

\section{Hydrolysis of Crude Antibiotic Complex and Isolation of Aglycones}

A solution of $500 \mathrm{mg}$ of crude antibiotic complex in $20 \mathrm{ml}$ of $0.1 \mathrm{~N}$ hydrochloric acid was heated at $90^{\circ} \mathrm{C}$ for 60 minutes. The reaction mixture was extracted with $80 \mathrm{ml}$ of ethyl acetate. The ethyl acetate layer was dehydrated over sodium sulfate and evaporated in vacuo to give $200 \mathrm{mg}$ of yellow powder. The aglycone mixture thus obtained was further purified by column chromatography on silica gel developed with methylene chloride. Appropriate fractions were evaporated in vacuo to yield $28 \mathrm{mg}$ of sulfurmycinone, $14 \mathrm{mg}$ of auramycinone and $55 \mathrm{mg}$ of aklavinone $\left(\mathrm{mp} 170^{\circ} \mathrm{C}\right)$. 
Sulfurmycinone: $\operatorname{mp~} 159^{\circ} \mathrm{C} ;[\alpha]_{\mathrm{D}}^{20}+232.2^{\circ}\left(c 0.1, \mathrm{CHCl}_{3}\right) ; \nu_{\max }^{\mathrm{KBr}} \mathrm{cm}^{-1} 1740,1710,1675,1620$; $\operatorname{PMR}\left(\mathrm{CDCl}_{3}\right) \delta$ in ppm 12.71 (s), 12.01 (s), 7.79 (d), 7.67 (t), 7.64 (s), 7.30 (d), 5.23 (m), 4.81 (s), 4.35 (s), 3.83 (d), 3.68 (s), 2.91 (d), 2.68 (d), 2.42 (d, d), 2.27 (d), 2.27 (s); M.W. 440; Anal. Found: C 62.84, H 4.51, O 32.65: Calcd. for $\mathrm{C}_{23} \mathrm{H}_{20} \mathrm{O}_{9}$ : C 62.71, H 4.58, O 32.71, M.W. 440.1.

Auramycinone: $\mathrm{mp} 153.5^{\circ} \mathrm{C} ;[\alpha]_{\mathrm{D}}^{20}+178.0^{\circ}\left(c 0.1, \mathrm{CHCl}_{3}\right) ; \nu_{\max }^{\mathrm{KBr}} \mathrm{cm}^{-1} 1735,1675,1620$; PMR $\left(\mathrm{CDCl}_{3}\right) \delta$ in ppm $12.74(\mathrm{~s}), 11.95(\mathrm{~s}), 7.83(\mathrm{~d}), 7.70(\mathrm{~s}), 7.69(\mathrm{t}), 7.31(\mathrm{~d}), 5.38(\mathrm{~m}), 4.06(\mathrm{~d}), 4.00(\mathrm{~s}), 3.71$ (s), 3.34 (d), 2.64 (d, d), 2.22 (d), 1.43 (s); M.W. 398; Anal. Found: C 63.05, H 4.51, O 32.44: Calcd. for $\mathrm{C}_{21} \mathrm{H}_{18} \mathrm{O}_{8}$ : C 63.33, H 4.56, O 32.11, M.W. 398.1.

Total Hydrolysis

Auramycin A: A solution of auramycin A $(100 \mathrm{mg})$ in $20 \mathrm{ml}$ of $0.1 \mathrm{~N}$ hydrochloric acid was heated at $90^{\circ} \mathrm{C}$ for 60 minutes. A yellow precipitate $(40 \mathrm{mg})$ was recovered and crystallized from an $n$-hexane chloroform mixture to give auramycinone $(30 \mathrm{mg})$ as yellow needles, $\mathrm{mp} 153.5^{\circ} \mathrm{C}$. The hydrochloric acid solution was neutralized and its sugar composition was examined by TLC. Three spots were detected with $p$-anisaldehyde-sulfuric acid: Rf values (color), 0.80 (greenish blue), 0.53 (grayish blue) and 0.12 (sky-blue). These were determined by direct comparison to be cinerulose A ( $\operatorname{Rf} 0.80$ ), 2deoxyfucose ( $\mathrm{Rf} 0.53$ ) and rhodosamine ( $\mathrm{Rf} 0.12$ ), respectively.

Partial Hydrolysis

Auramycin A: To auramycin A (100 mg) in $20 \mathrm{ml}$ of acetone, $20 \mu \mathrm{l}$ of concentrated hydrochloric acid was added. After standing for 40 minutes at room temperature, the reaction mixture was evaporated in vacuo. The residue was chromatographed and gave $35 \mathrm{mg}$ of yellow pigment (I) and $33 \mathrm{mg}$ of disaccharide (II).

Yellow pigment (I): $\mathrm{mp} 139.5^{\circ} \mathrm{C}$ (dec.); $[\alpha]_{\mathrm{D}}^{20}+189.3^{\circ}\left(c 0.1, \mathrm{CHCl}_{3}\right) ; \nu_{\max }^{\mathrm{KBr}} \mathrm{cm}^{-1} 1740,1680,1625$.

Auramycin B: To $100 \mathrm{mg}$ of auramycin B in $15 \mathrm{ml}$ of acetone was added $0.3 \mathrm{ml}$ of concentrated hydrochloric acid. After standing for 120 minutes at room temperature, the reaction mixture was evaporated in vacuo. The residue was chromatographed, and gave $28 \mathrm{mg}$ of yellow pigment (III), $\mathrm{mp}$ $139.5^{\circ} \mathrm{C}$, and $23 \mathrm{mg}$ of disaccharide (IV).

Hydrolysis of Yellow Pigment (I)

Yellow pigment (I) $\left(20 \mathrm{mg}\right.$ ) was hydrolyzed in $1 \mathrm{ml}$ of $0.1 \mathrm{~N}$ hydrochloric acid at $90^{\circ} \mathrm{C}$ for 60 minutes. The yellow precipitate was filtered off and dried to give $10 \mathrm{mg}$ of auramycinone as a yellow powder, $\mathrm{mp}$ $153.5^{\circ} \mathrm{C}$. The sugar in the filtrate was determined by TLC to be rhodosamine, mp $152^{\circ} \mathrm{C}$.

Hydrolysis of Yellow Pigment (III)

Yellow pigment (III) $(20 \mathrm{mg})$ was hydrolyzed in $1 \mathrm{ml}$ of $0.1 \mathrm{~N}$ hydrochloric acid at $90^{\circ} \mathrm{C}$ for 60 minutes. From the reaction mixture, sulfurmycinone, $\mathrm{mp} 159^{\circ} \mathrm{C}$, and rhodosamine, $\mathrm{mp} 152^{\circ} \mathrm{C}$, were obtained.

Acetylation of Disaccharide (II)

Disaccharide (II) (100 mg) obtained from auramycin A or sulfurmycin A was acetylated with acetic anhydride $(2.0 \mathrm{ml})$ in pyridine $(2.5 \mathrm{ml})$ for 16 hours at room temperature. The acetates were chromatographed by preparative TLC (cyclohexane - ethylacetate, $1: 1$ ) and gave two distinct bands, designated $\alpha$-diacetate and $\beta$-diacetate. From them, $25 \mathrm{mg}$ of $\alpha$-diacetate $\left([\alpha]_{\mathrm{D}}-175^{\circ}\right)$ and $32 \mathrm{mg}$ of $\beta$-diacetate $\left([\alpha]_{\mathrm{D}}-120^{c}\right)$ were obtained as colorless viscous liquids.

Acetylation of Disaccharide (IV)

Disaccharide (IV) (100 mg) obtained from auramycin B or sulfurmycin B was acetylated with acetic anhydride $(2.0 \mathrm{ml})$ in pyridine $(2.5 \mathrm{ml})$ for 16 hours at room temperature. From the reaction mixture, $23 \mathrm{mg}$ of $\alpha$-acetate $\left(\mathrm{mp} 123^{\circ} \mathrm{C}\right)$ and $25 \mathrm{mg}$ of $\beta$-acetate $\left(\mathrm{mp} 188^{\circ} \mathrm{C},[\alpha]_{\mathrm{D}}-128^{\circ}\right)$ were obtained as colorless crystals.

Partial Methanolysis

Auramycin A: To a solution of auramycin A $(200 \mathrm{mg})$ in $40 \mathrm{ml}$ of dry acetone were added $2 \mathrm{ml}$ of dry methanol and $1.5 \mathrm{ml}$ of $0.2 \mathrm{~N}$ hydrochloric acid in absolute methanol. After 40 minutes at room temperature, the reaction mixture was concentrated in vacuo and the product was separated into yellow pignent (I) and crude methyl glycoside by column chromatography on silica gel. The crude 
methyl glycoside was further purified by preparative TLC (chloroform - methanol, 10: 1) to give $85.7 \mathrm{mg}$ of pure methyl glycoside (V) as a colorless oil.

Methyl glycoside (V): $[\alpha]_{\mathrm{D}}-286^{\circ}\left(c 0.86, \mathrm{CHCl}_{3}\right) ; \nu_{\max }^{\mathrm{CCl}_{4}} \mathrm{~cm}^{-1} ; 3450,1730,1120,1100,1040 ; \mathrm{C}_{13} \mathrm{H}_{22^{-}}$ $\mathrm{O}_{8}\left(\mathrm{M}^{+}, 274.14\right.$ by high resolution mass spectrometry).

Auramycin B: To a solution of auramycin B $(200 \mathrm{mg})$ in $27.2 \mathrm{ml}$ of dry acetone were added $0.6 \mathrm{ml}$ of $0.2 \mathrm{~N}$ hydrochloric acid in absolute methanol. The mixture was allowed to stand at room temperature for 90 minutes. The reaction mixture was worked up as described in partial methanolysis of auramycin A to give $85 \mathrm{mg}$ of yellow pigment (III) and $20.8 \mathrm{mg}$ of methyl glycoside (VI).

Methyl glycoside (VI): $\mathrm{mp} 130^{\circ} \mathrm{C} ;[\alpha]_{\mathrm{D}}-221^{\circ}\left(c 0.2, \mathrm{CHCl}_{3}\right) ; \nu_{\max }^{\mathrm{Cl}_{4}} \mathrm{~cm}^{-1} 1730 ; \mathrm{C}_{13} \mathrm{H}_{20} \mathrm{O}_{6}\left(\mathrm{M}^{+}\right.$, 272.13 by high resolution mass spectrometry).

\section{Hydrogenolysis of Auramycin A and Other Glycosides}

Male Wistar rats were sacrificed by decapitation. Livers were excised and homogenized with a glass teflon homogenizer in a $0.15 \mathrm{M}$ potassium chloride solution and centrifuged at $9,000 \times g$ for 10 minutes. The supernatant thus obtained was used as the enzyme preparation. The reaction mixture, containing $40 \mathrm{ml}$ of enzyme preparation, $2 \mathrm{ml}$ of a solution of auramycin A $(10 \mathrm{mg} / \mathrm{ml}), 10 \mathrm{mg}$ of NADPH and $5 \mathrm{ml}$ of $0.1 \mathrm{M}$ tris-HCl buffer ( $\mathrm{pH} 7.8$ ), was allowed to stand for 45 minutes at $37^{\circ} \mathrm{C}$ anaerobically. At the termination of the reaction, $3.5 \mathrm{mg}$ of 7 -deoxyauramycinone, $\mathrm{mp} 200^{\circ} \mathrm{C}$, was obtained.

\section{Acknowledgements}

We would like to acknowledge the help of Dr. IsHITSUKA of our research center with antitumor activity testing.

\section{References}

1) Arcamone, F.: New antitumor anthracyclines. Lloydia 40: 45 66, 1977

2) Arcamone, F.: Daunomycin and related antibiotics. in Topics in Antibiotic Chemistry, Vol. 2, Ed. P. G. SAMMES, John Wiley \& Sons, p. 102 239, 1978

3) Oki, T.; Y. Matsuzawa, A. Yoshimoto, K. Numata, I. Kitamura, S. Hori, A. Takamatsu, H. Umezawa, M. Ishizuka, H. Naganawa, H. Suda, M. Hamada \& T. TAKeuchi: New antitumor antibiotics, aclacinomycins A and B. J. Antibiotics 28: 830 834, 1975

4) Kitamura, I.; N. Shibamoto, T. Oki, T. Inui, H. Naganawa, M. Ishizuka, T. Masuda, T. Takeuchi \& H. UMEZAWA: New anthracycline antibiotics, rhodirubins. J. Antibiotics 30: 616 618, 1977

5) Komiyama, T.; Y. Matsuzawa, T. Oki, T. Inui, Y. Takahashi, H. Naganawa, T. Takeuchi \& H. UmeZAWA: Baumycins, new antitumor antibiotics related to daunomycin. J. Antibiotics 30: 619 621, 1977

6) Nettleton, D. E.; J. A. Bush, W. T. Bradner \& R. H. Schreiber: Antibiotic compounds marcellomycin and musettamycin. U. S. Patent 4,039,736, Aug. 2, 1977 and 4,064,014, Dec. 20, 1977

7) Matsuzawa, Y.; A. Yoshimoto, T. Oki, T. Inui, T. Takeuchi \& H. Umezawa: New anthracycline antibiotics, roseorubicins A and B. J. Antibiotics 32: 420 424, 1979

8) Bradner, W. T.; J. A. Bush \& D. E. Nettleton: Antibiotic compound. U. S. Patent 4,112,071, Sep. 5, 1978

9) Nettleton, D. E.; T. W. Koyle \& W. T. Bradner: Antibiotic compound. U. S. Patent 4,123,608, Oct. 31,1978

10) Fujiwara, A.; T. Hoshino, M. Tazoe \& M. Fujiwara: Auramycins and sulfurmycins, new anthracycline antibiotics. Characterization of aglycones, auramycinone and sulfurmycinone. J. Antibiotics 34: 608 610,1981

11) Oki, T.; N. Shibamoto, Y. Matsuzawa, T. Ogasawara, A. Yoshimoto, I. Kitamura, T. Inui, H. NagaNAWA, T. TAKEUCH \& H. UmezaWA: Production of nineteen anthracyclic compounds by Streptomyces galilaeus MA-144-M1. J. Antibiotics 30: 683 687, 1977

12) Brockmann, H., Jr.; H. Budzikiewicz, C. KJerassi, H. Brockmann \& J. Niemeyer: Das massenspektroskopische Fragmentierungsverhalten der Anthracyclinone. Chem. Ber. 98: 1260 1269, 1965

13) Keller-Schierlein, W. \& W. Richle: Metabolic products of microorganisms. 86. Structure of cinerubine A. Antimicr. Agent Chemoth. 1970: 68 77, 1971

14) Oki, T.; I. Kitamura, Y. Matsuzawa, N. Shibamoto, T. Ogasawara, A. Yoshimoto, T. Inui, H. NagaNAWA, T. TAKEUCHI \& H. UMEZAWA: Antitumor anthracycline antibiotics, aclacinomycin A and analogues. II. Structural determination. J. Antibiotics 32: $801 \sim 819,1979$

15) Richle, W.; E. K. Windler, D. M. Hawley, M. Dobler \& W. Keller-Schierlein： Stoffwechselprodukte von Mikroorganismen. Die Struktur des Cinerbins B. Helv. Chim. Acta 55: 467 480, 1972 